\title{
TURKISH UNIVERSITY STUDENTS' CAUSAL ATTRIBUTIONS TO THEIR PERCEIVED ACHIEVEMENTS AND FAILURES IN LEARNING ENGLISH
}

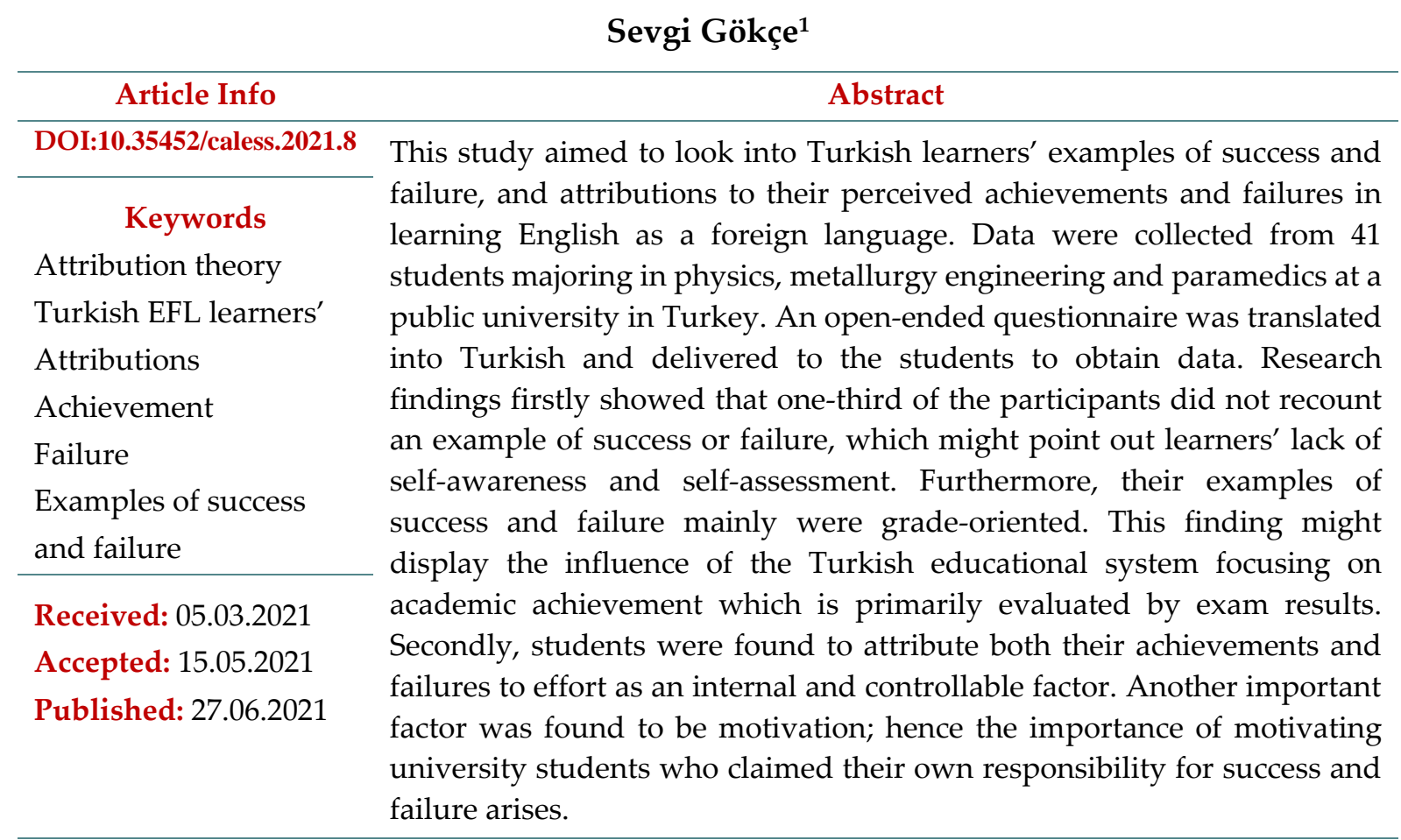

Cited as APA: Gökçe, S. (2021). Turkish university students' causal attributions to their perceived achievements and failures in learning English. International Journal of Current Approaches in Language, Education and Social Sciences (CALESS), 3 (1), 157-173.

\section{Introduction}

Learning a foreign language cannot be conceived as a simple process. In Turkey, it has extended almost two centuries (Çelebi, 2006), and the problems of this process have not been resolved yet. Issues of learning and teaching English were complainingly summarized by one of the former ministers of education in Turkey as follows: "Millions of courses have been run for years in this country, thousands of teachers have taught them and students have lost time in those courses. We have tried hard, still, we could not teach this language" (İngilizce öğretmeyi bilemedik, 2006). Several reasons for this situation are given as crowded classrooms, insufficient number and quality of English teachers, technological inadequacies, etc. (Akdoğan, 2010; Gömleksiz, 2002), but this study is rather concerned with detailing learners' personal reasons for their perceived success and failure in English with reference to Weiner's

\footnotetext{
1 (D) Eskişehir Osmangazi University, Turkey, sevgigokce@ ogu.edu.tr
} 
(1972) "attribution theory". Hence, this paper aims to give a brief account of Turkish university students' perceptions of achievements and failures in learning English and their causes from their perspective.

Learner achievement is the desired outcome of all educational processes, and how learners reach this desired point and what kinds of motivational and emotional drives influence their journey to success have been explained in various ways. Achievement theories constitute one of the explanations for learners' successes or failures, and among the achievement theories which take their foundations from psychology, "attribution theory" has an influential status and it has been a significant model for motivational studies since the 1980s (Dörnyei, 2005). According to the theory, people's causal attributions to success and failure are likely to determine their future actions. These causal attributions are luck, ability, effort, and the difficulty of the task which are labelled by Weiner (1972) as four salient determinants of success and failure. Weiner $(1972,1985)$ also puts forth three dimensions of the attributions: stability, controllability, and locus of control (being internal or external): Effort as unstable, controllable and internal; ability as stable, uncontrollable, and internal; task difficulty as stable, uncontrollable and external; luck as unstable, uncontrollable and external. The more unchangeable, uncontrollable and external attributions learners have, the more negative they feel about the learning process (Peacock, 2010; Williams Burden, Poulet \& Maun, 2004). Weiner (1972) also reviewed previous study results which demonstrate that successful students attribute their achievements to high effort and failures to low effort. In contrast, less successful students attribute their low achievements to a lack of ability. In other words, Weiner distinguished students as successful and less successful and based his theory on the attributional differences between these two groups of students.

In the literature, more attributions to these four salient determinants of success and failure labelled by Weiner (1972) were added. For instance, Little (1985) put 149 children's free responses into 18 attributions. In Williams et al.'s study (2004) 21 attributions for achievement and 16 attributions for failure emerged. Williams and Burden (2002) found more attributions than four, ranging from materials to mood. In their study with learners of French as a foreign language, younger learners gave the reasons of "listening and concentrating", that is effort, for their achievements; however, elder students tended to provide a wider range of attributions for their achievements like ability, task difficulty, circumstances, teacher, materials, mood, etc. Underachieving participants' attributions for failures somewhat ranged. Younger students in this group attributed their failures to "not listening or concentrating", "not practising", "not remembering or understanding" and task difficulty. In addition to these reasons, elderly learners reported more: "lack of ability", "poor teaching" and "lessons missed". Thus, the range of the attributions reported in the study was found slightly broader than the ones in the literature. Most importantly, Williams and Burden underlined the rarity of the cases articulating "intelligent effort", namely, "the 
application of appropriate strategies for achieving success in learning the foreign language" (p. 199).

Peacock (2010) extended his research scope and investigated 505 EFL university students' attributions in Hong Kong and 40 EFL teachers' opinions. He found out that learners and teachers stated various attributions for success, most of which were internal, unstable and controllable. However, a statistically significant difference was found between the two groups: Teachers attributed student success to effort, whereas students attributed their achievement and failure to luck. Secondly, in terms of attributing success to effort, female learners differed from their male counterparts. They were significantly more likely to attribute success to their efforts. Thirdly, while science students attributed success and failure to luck and task difficulty, humanities students tended to attribute success to a more internal factor, effort.

In terms of the importance of the attribution theory, Williams et al. (2004) note that causal attributions of learners may not necessarily reflect objective reasons. Still, they are more powerful to explain successes and failures than reasons put forth by other parties because "a very helpful source of information is likely to be contained within students' personal explanations for their successes and failures" (p. 20). They also suggest that based on some information about whether learners have detrimental attributions, learners can be trained to convert their attributions into more internal, changeable and controllable ones. Lebedina-Manzoni (2004) also underlines the need for looking into attributions to understand learners' problems better and to find appropriate methods to increase course effectiveness, success and personal satisfaction. Likewise, having a brief look at attributional findings in Turkish educational context may help us approach Turkish learners' problems better.

In Turkey, studies portray both teachers' and learners' causality of achievement. Can (2005) worked on Turkish elementary school teachers' perceptions of their achievements. Most of the teachers were found to attribute success to internal causes and failure to uncontrollable external causes. Their reasons for success were also identified to be more stable than the reasons for failure.

In accordance with Can's findings, Taşkıran (2010) reported that foreign language learners at preparatory school of a Turkish public university had more causal attributions for failure than for success. Success-oriented participants displayed significantly more internal, controllable, and relatively more stable attributional reasons than failure-oriented students, which was, she highlighted, a finding supported by literature on attribution theory.

Erten (2015) investigated $6^{\text {th }}$-grade and $10^{\text {th }}$-grade Turkish students' achievement attributions after releasing their latest English exam results. He found that students, in general, attributed their task performance to their teachers' input, their interest, and ability, which he interpreted as further support for Turkish learners' tendency to attribute exam performance to external and internal uncontrollable factors. He 
ascribed this result to non-western societies' respect and affection towards teachers and the teaching profession. On the other hand, he underlines the risk of sacrificing learner autonomy behind attributing exam performance to such uncontrollable factors.

Demir (2017) conducted a study about English language learners' attributions for their success and failure in speaking English at a preparatory school. He found that the participants ascribed their success and failure in speaking English mainly to personally controllable factors and internal causes like practice and perseverance. However, these factors were observed in the attributions for success considerably more than those made for failure. Besides, the attributions to success were more stable than those made to failure.

Since the research knowledge base in Turkey points out various results in different settings, more research might be needed to get a better grasp of Turkish foreign language learners' reasons for their achievements and failures. For instance, learners majoring in different departments at Eskişehir Osmangazi University who take compulsory basic English courses are observed to be quite demotivated and display a low rate of success. To illustrate, the recent average English score of learners at the physics department was 40 out of 100. Furthermore, irregular attendance to English courses was noted by instructors of these groups. In such a situation, exploring learners' causal attributions to their achievements and failures is needed in the ELT field as Williams et al. (2004) point out a shared discourse exists among students about why they can learn or not.

Additionally, in this study learners' perceptions of success and failure are revealed based on their first-hand individual experiences. Studies deal with how learners conceptualize these notions in the form of definitions (Taşkıran, 2010). Still, personal accounts of achievements and failures deserve attention because individual experiences form a central lens for understanding people (Creswell, 2005). Thus, to understand learner attributions to success and failure better, how learners look at these concepts could be clarified.

Finally, unlike some previous studies (Taşkıran, 2010; Weiner, 1972; Williams et al., 2004 ) this study does not compare attributions of success-oriented learners and failureoriented learners because classifying individuals into fixed groups may yield misleading results. Every learner undergoes complex emotional and cognitive processes during language learning, their senses of "self" as successful or unsuccessful are changeable (Dörnyei, 2005) and their inclination to success and failure may be easily influenced by learning conditions; thus a general overview of learners' causal attributions to success and failure can help us understand Turkish language learners better. In this study, the participants' attributions other than the four attributions in Weiner $(1972,1985)$ are examined as well. 


\section{Method}

The study was designed as a survey study in which participants were asked openended questions about their examples of success and failure, and attributions to their perceived achievements and failures in learning English. In order to ensure that participants could freely express their ideas, an open-ended questionnaire was taken from Williams and Burden (2002) and Williams et al. (2004) The risk of influencing data with pre-determined categories as in a multiple-choice questionnaire was avoided because of the context-specific and personal features of attributions (Taşkıran, 2010).

After the questionnaire items were translated, back-translated and checked in terms of equivalence by an English teacher, Turkish version of the questionnaire was distributed to the respondents. Convenience sampling was applied in the study and the researcher gathered opinions of her students whose demotivation for learning English and high rate of absenteeism in classes drew the researcher's attention as an instructor. The participants were 41 first-year students ageing between 18 and 22 . Nineteen of them were male, and 22 of them were female students majoring in physics, metallurgy engineering, and paramedics at Eskişehir Osmangazi University. These students came from mathematics- and science-oriented sections at high schools. Owing to the exclusion of English in the process of getting prepared for the University Entrance Exam in Turkey, they had only studied subject areas included in that exam at the expense of English at high school. Since the participants' language learning process underwent such a serious interruption, their responses about this process might reveal clues as to their causal perceptions related to success and failure. In addition, as their departmental programs did not involve courses requiring English as a medium of instruction, learners did not have intensive English instruction. Instead, they received three hours of English courses weekly for two semesters as English I and English II. The syllabus of courses was dependent on an elementary-level coursebook that covered basic grammar rules and the skills of reading, listening, speaking and writing. However, learners were only tested for their grammatical and lexical knowledge, which posed the danger that learners might not assign the same importance to the four language skills as the importance they assigned to grammar and vocabulary. Furthermore, despite being mandatory, English courses were noncredit; that is, learners' grades from basic English courses appeared as either "pass" or "fail" in their transcripts. The risk here was that since 50 out of 100 was accepted as a yardstick to pass this course, getting 50 from examinations sufficed for many students, so they gave a low priority to learning English. They preferred rote learning of rules and words, which they believed to save them in multiple-choice examinations. In sum, they tended to see English not as a way of communication but as a set of arbitrary rules to memorize and as a course to take involuntarily and to pass immediately. Consequently, they complained about learning grammatical rules of English but being unable to communicate by it. 
In this educational context, the research was carried out to answer the research questions below:

1. What are EFL learners' examples of success and failure in learning English?

2. What are EFL learners' causal attributions for success and failure?

Learners' responses to open-ended questions were analyzed qualitatively in two steps. Their short answers were first read through, analyzed, and put into categories by the researcher. To validate the accuracy of categories, the measure of conducting an "external audit" (Creswell, 2005) was taken. An English teacher who was a PhD candidate in English language teaching and who did not take part in the study checked the categorizations and gave feedback.

\section{Findings}

At the beginning of the questionnaire, the extent of the participants' feeling of success or failure was investigated. The question "How well do you think you are doing at English?" was answered by most of the students as "I sometimes do well in English" ( $\mathrm{N}=21)$ and by 9 students as "I usually do well in English". 11 students answered as "I don't often do well in English", but none of the students chose the option of "I never do well in English". It was understood that the majority of the participants $(\mathrm{N}=30)$ saw themselves closer to success.

Research Question 1: What are EFL learners' examples of success and failure in learning English?

The participants' examples of their achievements can be seen in the table below.

Table 1.Frequencies of the participants' examples of their achievements

Left blank: 13

Answered negatively: 4

Getting high grades

From exams: 8

From assignments: 4

\begin{tabular}{ll}
\hline Completing a translation task & 4 \\
\hline Talking to foreigners & 4 \\
\hline Reading & 2 \\
\hline Other & 4 \\
\hline TOTAL & $43^{*}$ \\
\hline
\end{tabular}

*2 students gave more than one example. 
Despite the significant number of the participants feeling successful to an extent, a significant number of students $(\mathrm{N}=17)$ could not articulate a successful event in their language learning process. 12 students labelled "getting high grades" from exams and assigned tasks as an achievement. Completing a translation task was not related to assignments given by a teacher; in fact, they were done in order to help another person who did not speak English. "Talking to foreigners" was related to supporting and guiding tourists by giving directions. "Reading" was related to the participants' finishing reading written material. In the category of "other", activities of playing English computer games, English songs (listening to or singing them was not specified), English theatre (watching or staging a play was not specified) and reading aloud with good pronunciation in a ceremonial event were mentioned.

Secondly, the participants' examples of their failures are put into the table below.

Table 2.Frequencies of the participants' examples of their failures

Left blank: 17

Answered negatively: 4

Getting low grades

Whole learning past

3

Incompletion of a writing task

2

Other

Unrelated

5

TOTAL

Like the figures related to achievement, half of the participants did not give a specific example of their failures. 8 students gave low exam grades as examples, and 3 students accounted for their whole language learning process as a failure. Other examples of failure were being unable to talk to a foreigner and dialogues and grammar (not specified).

The results of the first research question related to achievement and failure had two points in common: Absence of examples and grade-oriented examples. Although the meaning of success and failure may change from person to person, every student's learning history is expected to record some events as achievements and some as failures. Considering the participants' foreign language learning process extending over years starting from primary school, we expect several achievements and failures to have taken place in this long period. For this reason, a considerable number of learners' expressing nothing as achievement and failure in this study may raise 
questions. The second frequent response was grade-oriented examples. With respect to achievements, the participants remembered getting good grades mostly from exams or assignments, and concerning failures, they remembered low grades.

Research Question 2: What are EFL learners' causal attributions for success and failure?

The questionnaire items required the participants to write down four causes for their achievements and failures. Firstly, the participants' causal attributions to success are tabulated.

Table 3. Frequencies of the participants' causal attributions for their achievements

\begin{tabular}{lc}
\hline Intrinsic motivation & 19 \\
\hline Effort & 18 \\
\hline Teacher & 13 \\
\hline Technology & 12 \\
\hline Background knowledge & 8 \\
\hline Extrinsic motivation & 7 \\
\hline Low task difficulty & 3 \\
\hline Ability & 1 \\
\hline Personality & 1 \\
\hline Educational system & 1 \\
\hline Luck & 1 \\
\hline Unrelated & 2 \\
\hline TOTAL & 86 \\
\hline
\end{tabular}

Before elaborating on the categories above, it would be appropriate to clarify the dichotomy of intrinsic and extrinsic motivation. Dörnyei (1994) defines intrinsic and extrinsic types of motivation based on internal reward and external reward or punishment. In this study, learner responses which are grouped under the category of intrinsic motivation refer to the joy of learning English, curiosity and interest as reasons for success. In contrast, attributing success to extrinsic motivation is related to external driving forces of good job opportunities, social status, mandatory nature of English lessons, etc. While the number of the participants who attributed success to extrinsic motivation is not deniable, the participants attributing achievement to intrinsic motivation far outnumber them. 
18 students thought that they harvested the fruits of their effort, but 13 students honoured their teachers' efforts, which was also found in studies conducted in nonWestern contexts respecting teachers and the teaching profession (Erten, 2015). 12 students revealed that they could not help but learn English as a result of their using a computer, playing online games, and surfing the Internet. Background knowledge was mentioned by 8 students and task difficulty which referred to the level of examinations was expressed by 3 students. Ability, personality, luck and educational system were the causes of perceived achievement for one student each.

Table 4. Frequencies of the participants' causal attributions for their failures

\begin{tabular}{lc}
\hline Lack of effort & 19 \\
\hline Insufficient background knowledge & 13 \\
\hline Lack of intrinsic motivation & 12 \\
\hline Teacher & 10 \\
\hline Poor educational system & 4 \\
\hline Personality & 2 \\
\hline Lack of extrinsic motivation & 1 \\
\hline Bad luck & 1 \\
\hline Lack of ability & 1 \\
\hline TOTAL & 63 \\
\hline
\end{tabular}

Similar to the results above, the most frequently mentioned reason for failure was lack of spending effort which was followed by insufficient background knowledge. 12 learners pointed out that lack of intrinsic motivation for language learning causes their low achievement. 10 learners found their teachers responsible while 4 learners laid responsibility on the Turkish educational system which, they claimed, recycled the same content every year. Lack of extrinsic motivation, bad luck and lack of ability were causal attributions of failures of 3 students each.

In sum, while most of the participants attributed their successes and failures to internal factors (effort, intrinsic and extrinsic motivation, background knowledge, personality and ability) an unignorable number of students attributed them to external factors of teachers, educational system, technology, task difficulty, and luck. Notably, the emergence of effort as the primary attribution was in line with the findings of previous research (Can, 2005; Taşkıran, 2010; Williams \& Burden, 2002; Yavuz \& Höl, 2017) 


\section{Discussion, Conclusion, and Suggestions}

In response to the first research question about examples of success and failure, some participants' leaving the related questionnaire item blank is worth pondering over. It may signal learners' unawareness of their achievements and failures and lack of selfassessment in language learning. Thamraksa (2005) puts forward the main difference between proficient and less proficient learners as "metacognition" which refers to the conscious ability to master knowledge and the learning process. Thamraksa states that metacognition enables learners to know themselves, tasks and learning strategies. In this research, learners' unawareness of their achievements and failures may indicate their distance to the notion of metacognition. If these students had been trained to use such metacognitive strategies as making preparations and plans for learning, selection of learning strategies, monitoring oneself, and self-evaluation (Thamraksa, 2005), they would probably have become more self-aware and ready to take responsibility for their learning. Zimmerman (2002) stresses self-awareness as integral to learners' monitoring their performance selectively for signs of progress. Thus, metacognitive training should start at earlier levels of education so that learners can realistically monitor themselves and their progress in all areas.

Learners' being unable to write an example of success or failure might also be due to lack of receiving sufficient individual feedback as a result of receiving education in crowded classrooms (Akdoğan, 2010; Gömleksiz, 2002). When teacher feedback is not possible in such situations, peer feedback can be resorted to help learners see their achievements and failures from different perspectives (Tsang \& Wong, 2002). Other feedback strategies can be students' self-reflection, in-class discussions, or focus interviews with students (Klimova, 2015). By means of using different ways of feedback, feedback procedure may not be sacrificed as feedback practice helps clarify expected standards of good performance and facilitates the development of selfassessment in learning (Nicol \& Macfarlane-Dick, 2006).

Secondly, an important number of students' accounting for high or low grades as the memorable examples of success or failure may be one of the inevitable outcomes of exam-centred education in Turkey as the Turkish educational system focuses on academic achievement, and this academic achievement is evaluated by exam results (Kara, 2020). If learners' learning experiences are by and large composed of listening to teachers' presentation and being checked for comprehension in tests, learners may not easily detail past achievements or failures apart from exam results.

Additionally, learners' grade-oriented examples of success and failure may signal problems in teaching, assessment and instructional context. Akdoğan (2010) came up with a list of problems of foreign language teaching in Turkey which included lack of teaching materials, traditional teaching methods, and overemphasis on grammarbased questions directed to learners in public examinations. Accordingly, the need for reform in foreign language education at high schools was reported by British Council and TEPAV (2015). Therefore, in addition to the implementation of educational 
reform, language classrooms should be enriched with various activities appealing to learners' learning styles which may yield more learner achievements and save learners from seeing their "whole learning past" like a failure as shown in the study.

The achievement examples except for the grade-oriented ones in this study appear to be more representative of the participants' perceived successes independent of an authority's grade-related judgment. Based on these success stories, the notion of "success" may evolve into a more real-life and individualized form beyond getting high grades. Moreover, the effect of success stories could also be maximized by wholeclass sharing, and rewarding active learners like nomination on school bulletin (Loi \& Uyen, 2016). On the other hand, failures could be discussed and critically evaluated in different forms of feedback as mentioned before. In this way, failures can be taken as a starting point for new achievements, and learners can identify and realize their strengths and weakness, which encourages personal and professional growth (Klimova, 2015). It may also affect learners' viewpoints about causalities of success, which can be further investigated.

In response to the second question, participants mostly attribute their achievements and failures to intrinsic motivation and effort. Since both are controllable and internal factors (Williams et al., 2004), the participants who give this response can be seen ready to take responsibility for their learning (Weiner, 1972) and they are more likely to try again when they fail (Dörnyei, 2005). Even if they fail, participants' perceiving internal and more controllable factors like effort as reasons for their achievements and failures may be an advantage for language teachers because volitional undertaking of selfresponsibility increases the probability of achievement (Weiner, 1972). Thus, together with a product-oriented approach in assessment which generally ends up with assessing a learner's product, a process-oriented approach in assessment should be adopted so that learners can be given more than one chance to try, and their on-task enthusiasm and effort can be taken into account.

For learners who state that they owe their success to technology, opportunities could be created to display their performances in learning English. Target words, functions or structures they learn from games, films, TV serials, social media platforms and websites can be shared regularly in classes and be added to the curriculum. Assignments can be given to students to find what is learned in the classroom in these technological spaces. Kirriemuir and McFarlane (2006) suggest integrating "lite" versions of mainstream digital games into primary and secondary educational programs by adapting their components into instruction and adding curriculumrelevant tasks and content.

A significant number of students attribute their achievements and failures to teachers, which was also found in Erten's (2015) study. Honoring teachers might be a cultural issue as Erten suggested, but learners should be taught that both achievements and failures are primarily related to oneself. In this respect, Mohammadi and Sharififar 
(2016) highlight the role of teachers in raising learners' consciousness about the potential influence of internal and external factors on learners' lives and their language achievements. Learning logs, diaries and journals (Benson, 2001, 2006; Little, 1997) can be the introspective devices to initiate this consciousness-raising.

The result that intrinsic motivation is the second most frequent reason behind learners' achievements and the third most frequent reason for failures reminds the necessity of making English lessons fun. This finding underlines the significance of arousing students' interests to make them actively participate in lessons, understand the content better and feel successful. As Dörnyei (2005) stresses, without sufficient motivation, individuals cannot achieve their long-term goals no matter how appropriate the curriculum is.

Another causality perceived by learners is between background knowledge and success or failure. Learners who gave these responses are assumed to refer to grammatical and vocabulary knowledge because none of the students mentioned their background about the four language skills. Hence, this finding might be another repercussion of the form-focused nature of teaching and testing practices in Turkey, which was reported in Akdoğan (2010). Since learners' strengths or weaknesses in background knowledge are restricted to the ones in grammatical and lexical knowledge because of common teaching and testing practices at institutions, the remaining language skills and areas should be taught and tested so that they can constitute indispensable parts of language learning (Paker, 2012).

The remaining factors of task difficulty, personality, ability, and bad luck, which were mentioned by fewer participants, are rather uncontrollable ones. However, the number of students who attribute their achievements and failures to uncontrollable factors should be diminished because these thoughts may bring about "learned helplessness". Maier and Seligman (1976) who introduced this notion hypothesized that "when events are uncontrollable, the organism learns that its behaviour and outcomes are independent, and this learning produces the motivational, cognitive, and emotional effects of uncontrollability" (p. 3). Weiner (1972) also calls learned helplessness as "an appropriate label for the low achievement syndrome, since persons low in achievement motivation do not perceive that effort influences outcome" ( $p$. 210). In line with these definitions, Hashemi and Zabehi (2011) found a correlation between internal and external control attribution with scores on tests; that is, the researchers define effort attribution as the best predictor of high scores and task difficulty attribution as the best predictor of low scores. For this reason, learners who assume that language tasks in a test are too difficult are likely to get lower scores, and when their assumptions come true, they may fall into the feeling of learned helplessness about language learning. This feeling may lead to the vicious circle of underachievement by giving up studying (Fogle, 1978).

In conclusion, the study of attribution theory has much future scope (Dörnyei, 2005) as it is closely linked to several notions in educational psychology like motivation, 
metacognition, and learned helplessness as shown in this research. In addition, EFL learners' examples of perceived achievements and failures are set forth. However, one of the limitations of this research is that it is restricted to learners' short written accounts gathered in a limited time. For future research, a qualitative and longitudinal study can be conducted based on extreme or deviant case sampling in which the most and the least successful students are chosen because such cases provide rich information (Patton, 1990). Participants may detail their achievements and failures by writing a learner autobiography as learner autobiographies help comprehend learners' contexts, viewpoints, tensions and conflicts under certain circumstances (Posada-Ortíz \& Garzón-Duarte, 2019). Moreover, possible changes in their causal attributions throughout their language learning process can be found by regular data collection through self-assessment and reflection. In this way, learner attributions can be better understood and the effectiveness of language teaching can be evaluated.

\section{References}

Akdoğan, S. (2010). Teachers' and instructors' views about the problems experienced in foreign language teaching in Turkey and foreign language schools as a proposal for solution [Unpublished MA thesis]. Frrat University, The Institute of Social Sciences.

Benson, P. (2001). Teaching and researching autonomy in language learning. Pearson Education.

Benson, P. (2006). Autonomy in language teaching and learning. Language Teaching, 40, 21-40. https://doi.org/10.1017/S0261444806003958

British Council \& TEPAV (2015). Türkiye'de yükseköğretim kurumlarındaki Ingilizce eğitimi. Yorum Basın Yayın.

Can, B. (2005). An analysis of elementary school teachers' causal attributions related to selfidentified success and failure [Unpublished master's thesis]. Boğaziçi University, Institute of Social Sciences.

Creswell, J.W. (2005). Educational research: Planning, conducting, and evaluating quantitative and qualitative research. Pearson Prentice Hall.

Çelebi, M.D. (2006). Türkiye'de anadili eğitimi ve yabancı dil öğretimi. Erciyes Üniversitesi, Sosyal Bilimler Enstitüsü Dergisi, 21 (2), 285-307. https://dergipark.org.tr/en/download/article-file/219375

Demir, Y. (2017). Turkish EFL learners' attributions for success and failure in speaking English. International Journal of Contemporary Educational Research, 4 (2), 39-47. https://files.eric.ed.gov/fulltext/EJ1207565.pdf

Dörnyei, Z. (1994). Motivation and motivating in the foreign language classroom. The
Modern
Language
Journal,
78
(3),
273-284.

http://www.jstor.org/stable/330107?origin=ISTOR-pdf 
Dörnyei, Z. (2005). The psychology of the language learner: Individual differences in second language acquisition. Lawrence Erlbaum.

Erten, İ. H. (2015). Age related gender differences in causal attributions of Turkish learners of English as a foreign language. ELT Research Journal, 4(2), 129-146. https://dergipark.org.tr/en/download/article-file/296303

Fogle, D. O. (1978).Learned helplessness and learned restlessness. Psychotherapy: Theory, Research and Practice, 15 (1), 39-47. http://www.csun.edu/ ainslab/readings/Anna/Fogle Learned\%20helplessness.pdf

Gömleksiz, M.N. (2002). Üniversitelerde yürütülen yabanc1 dil derslerine ilişkin öğrenci görüşlerinin değerlendirilmesi (Furat Üniversitesi örneği). Fırat Üniversitesi Sosyal Bilimler Dergisi, 12 (1), 143-158. https://dergipark.org.tr/en/download/article$\underline{\text { file/71986\#page }=147}$

Hashemi, M. R., \& Zabihi, R. (2011). Learners' attributional beliefs in success or failure and their performance on the interchange objective placement test. Theory $\mathcal{E}$ Practice in Language Studies, 1(8), 954-960. https://doi.org/10.4304/tpls.1.8.954-960

İngilizce öğretmeyi bilemedik. (April 27, 2006). Radikal.

http://www.radikal.com.tr/turkiye/ingilizce-ogretmeyi-bilemedik-778735/

Kara, M. (2020). Eğitim paydaşlarının görüşleri doğrultusunda Türk eğitim sisteminin sorunları. Ahi Evran Üniversitesi Kırşehir Eğitim Fakültesi Dergisi, 21(3), 1650-1694. https://doi.org/10.29299/kefad.853999

Kirriemuir, J., \& McFarlane, A. (2006). Literature review in games and learning. Report 8, 1-35. Bristol: Futurelab Series.

https://lchc.ucsd.edu/tclearninglounge/ROOT/Camille/readings/kirriemuir lit\%20on \%20games.pdf

Klimova, B. (2015). The role of feedback in EFL classes. Procedia-Social and Behavioral Sciences, 199, 172-177. https://doi.org/10.1016/j.sbspro.2015.07.502

Lebedina-Manzoni, M. (2004). To what students attribute their academic successes and unsuccesses. Education, 124 (4), 699-708.

http://web.b.ebscohost.com/ehost/pdfviewer/pdfviewer?vid=0\&sid=1a00ba6f-49f14610-b1fc-b75f3f31ce6f\%40sessionmgr103

Little, A.W. (1985). The child's understanding of the causes of academic success and failure: a case study of British schoolchildren. British Journal of Educational Psychology, 55 (1), 11-23. https://doi.org/10.1111/j.2044-8279.1985.tb02601.x

Little, D. (1997). Language awareness and the autonomous language learner. Language Awareness, 6 (2\&3), 93-104. https://doi.org/10.1080/09658416.1997.9959920

Loi, D. P., Thi, N., \& Uyen, L. (2016). Motivating EFL classroom participation by rewarding at a language center in Ho Chi Minh City, Vietnam. Journal of Applied 
Linguistics and Language Research, 3(5), 177-189.

http://www.jallr.com/index.php/JALLR/article/view/378/pdf378

Maier, S.F., \& Seligman, M.E. (1976). Learned helplessness: Theory and evidence. Journal of Experimental Psychology: General, 105 (1), 3-46. https://doi.org/10.1037/0096$\underline{3445.105 .1 .3}$

Mohammadi, A., \& Sharififar, M. (2016). Attributions for success and failure: Gender and language proficiency differences among Iranian EFL learners. Theory and Practice in Language Studies, 6(3), 518. http://dx.doi.org/10.17507/tpls.0603.09

Nicol, D.J., \& Macfarlane-Dick, D. (2006). Formative assessment and self-regulated learning: a model and seven principles of good feedback practice. Studies in Higher Education, 31 (2), 199-218. https://doi.org/10.1080/03075070600572090

Paker, T. (2012). Türkiye'de neden yabancı dil (İngilizce) öğretemiyoruz ve neden öğrencilerimiz iletişim kurabilecek düzeyde İngilizce öğrenemiyor? Pamukkale University Journal of Education, 32 (2), 89-94. https://doi.org/10.9779/PUJE563

Patton, M. (1990). Qualitative Evaluation and Research Methods. Sage Publications.

Peacock, M. (2010). Attribution and learning English as a foreign language. ELT Journal, 64 (2), 184-193. https://doi.org/10.1093/elt/ccp031

Posada-Ortiz, J. \& Garzón-Duarte, E. (2019). Autobiographies: a tool to depict English language learning experiences. GiST Education and Learning Research Journal, 18, 161179. https://doi.org/10.26817/16925777.447

Taşkıran, A. (2010). Exploring EFL Students' Causal Attributions of Perceived Success and Failure in Language Learning Process. [Unpublished master's thesis]. Anadolu University, Institute of Educational Sciences.

Thamraksa, C. (2005). Metacognition: A key to success for EFL learners. BU Academic Review, 4(1), 95-99.

https://citeseerx.ist.psu.edu/viewdoc/download?doi=10.1.1.533.6137\&rep=rep1\&type $=\mathrm{pdf}$

Tsang, W. K., \& Wong, M. (2002). Conversational English: An interactive, collaborative, and reflective approach. Richards, J. C. \& Renandya, W. A. (Eds.) Methodology in Language Teaching: An Anthology of Current Practice (pp. 212-224). Cambridge University Press.

Weiner, B. (1972). Attribution theory, achievement motivation, and the educational process. Review of Educational Research, 42 (2), 203-215. https://doi.org/10.2307/1170017

Weiner, B. (1985). An attributional theory of achievement motivation and emotion. Psychological Review, 92 (4), 548-573. https://doi.org/10.1037/0033-295X.92.4.548 
Williams, M., \& Burden, R. (2002). Students' developing conceptions of themselves as language learners. The Modern Language Journal, 83 (2), 193-201. https://doi.org/10.1111/0026-7902.00015

Williams, M., Burden, R., Poulet, G., \& Maun, I. (2004). Learners' perceptions of their successes and failures in foreign language learning. The Language Learning Journal, 30 , 19-29. https://doi.org/10.1080/09571730485200191

Yavuz, A., \& Höl, D. (2017) Investigation of Turkish EFL learners' attributions on success and failure in learning English. Journal of Language and Linguistic Studies, 13(2), 379-396. https://dergipark.org.tr/en/download/article-file/440778

Zimmerman, B.J. (2002). Becoming a self-regulated learner: an overview. Theory into Practice, 41 (2), 64-70. https://doi.org/10.1207/s15430421tip4102 2 


\section{Appendix I}

English Version of the Questionnaire

Age:

Gender: $\square$ Female $\square$ Male

1. Tick one answer $\square$

How well do you think you are doing at English?

I usually do well in English $\square$

I sometimes do well in English $\square$

I don't often do well in English $\square \quad$ I never do well in English $\square$

2. Give an example of when you did well.

3. When I do well at learning English the main reasons are:

$(4)$

4. Give an example of when you did not do well.

5. When I don't do well at English the main reasons are:

$(1)$

(2)

(3)

(4)

\section{Appendix II}

Turkish Version of the Questionnaire

Değerli katılımcı,

$\mathrm{Bu}$ anket İngilizce öğrenim sürecinizle ilgili hazırlanmıştır. Yanıtlarınız notla değerlendirilmeyecektir. Lütfen soruları içtenlikle yanıtlayınız.

Katkılarınız için teşekkürler.

Yaşınız:

\section{Cinsiyetiniz: $\square$ Kadın \\ $\square$ Erkek}

Bölümünüz:

1) İngilizcede ne kadar başarılı olduğunuzu düşünüyorsunuz? (Yalnızca bir şıkkı işaretleyiniz)

$\square$ Genellikle başarılıyım. değilim.

Çoğu zaman başarılı

$\square$ Bazen başarılıyım. değilim.

2) Geçmişte İngilizcede başarıyla yaptığınız bir şeye örnek verin.

3) İngilizcede başarılı olduğumda ana nedenler şunlardır:

1.

2.

3

4.

4) Geçmişte İngilizcede başarısız olduğunuz bir şeye örnek verin.

5) İngilizcede başarısız olduğumda ana nedenler şunlardır:

1.

4. 